\title{
Elemental composition of vegetables cultivated over coal-mining waste
}

\author{
JAIRO J. ZOCCHE ${ }^{1}$, PAULA ROHR ${ }^{2}$, ADRIANI P. DAMIANI' ${ }^{2}$, DANIELA D. LEFFA ${ }^{2}$, MIRIAM C. \\ MARTINS ${ }^{2}$, CAROLINE M. ZOCCHE ${ }^{1}$, KARINA O. TEIXEIRA ${ }^{2}$, GABRIELA D. BORGES ${ }^{2}$, MAIELLEN \\ M. DE JESUS ${ }^{2}$, CARLA E.I. DOS SANTOS ${ }^{3}$, JOHNNY F. DIAS ${ }^{3}$ and VANESSA M. DE ANDRADE ${ }^{2}$
}

\footnotetext{
${ }^{1}$ Laboratório de Ecologia de Paisagem e de Vertebrados, Programa de Pós-Graduação em Ciências Ambientais, Universidade do Extremo Sul Catarinense/UNESC, Avenida Universitária, 1105, Bairro Universitário, 88806-000 Criciúma, SC, Brazil ${ }^{2}$ Laboratório Biologia Celular e Molecular, Programa de Pós-Graduação em Ciências da Saúde, Universidade do Extremo Sul Catarinense/UNESC, Avenida Universitária, 1105, Bairro Universitário, 88806-000 Criciúma, SC, Brazil

${ }^{3}$ Laboratório de Implantação Iônica, Instituto de Física, Universidade Federal do Rio Grande do Sul/ UFRGS, Avenida Bento Gonçalves, 9500, Campus Vale, 91501-970 Porto Alegre, RS, Brazil
}

Manuscript received on March 27, 2017; accepted for publication on June 29, 2017

\begin{abstract}
We assessed elemental composition of the liver in mice subjected to one-time or chronic consumption of the juice of vegetables cultivated in a vegetable garden built over deposits of coal waste. Lactuca sativa L. (lettuce), Beta vulgaris L. (beet), Brassica oleracea L. var. italica (broccoli) and Brassica oleracea L. var. acephala (kale) were collected from the coal-mining area and from a certified organic farm (control). Elemental composition was analyzed by particle-induced X-ray emission (PIXE) method. Concentrations of $\mathrm{Mg}, \mathrm{S}$, and $\mathrm{Ca}$ of mice subjected to one-time consumption of broccoli and concentrations of these same elements plus $\mathrm{Si}$ of mice receiving kale were higher in the coal-mining area. Concentrations of $\mathrm{P}, \mathrm{K}$, and $\mathrm{Cu}$ were increase after chronic consumption of lettuce from the coal-mining area, whereas the levels of $\mathrm{Si}$, $\mathrm{P}, \mathrm{K}, \mathrm{Fe}$, and $\mathrm{Zn}$ were higher in the group consuming kale from the coal-mining area. Our data suggests that people consuming vegetables grown over coal wastes may ingest significant amounts of chemical elements that pose a risk to health, since these plants contain both essential and toxic metals in a wide range of concentrations, which can do more harm than good.
\end{abstract}

Key words: Coal, anthropogenic soil, trace elements, heavy metals, plants, PIXE.

\section{INTRODUCTION}

Despite its poor environmental reputation, coal represents an important source of energy worldwide (Zakrzewski 1991, Chen et al. 2005, Bhuiyan et al. 2010, León-Mejia et al. 2011, Council 2013) because between 27\% (Bhuiyan et al. 2010)

Correspondence to: Jairo José Zocche

E-mail: jjz@unesc.net and 40\% (Council 2013) of the world's energy consumption originates from incineration of coal.

Among all fossil energy sources, coal is considered the most pollutant one because it contains key polluting compounds such as sulfur dioxide (Zakrzewski 1991, Chen et al. 2005). Coal-mining operations are characterized as an environmental challenge (Bhuiyan et al. 2010, Bian et al. 2010, Council 2013, Wang et al. 2013) given 
that they degrade significant areas and replace the existing ecosystems with mine spoil dumps (Singh et al. 2004).

Overall, the system of coal energy production involves coal-mining, mineral processing, coal burning, and subsequent energy generation, whereas the environmental challenges from coal exploitation include coal mine accidents (Bian et al. 2010), land subsidence (Bian et al. 2010, Sadhu et al. 2012), damage to the water and terrestrial environment (Bian et al. 2010, Zocche et al. 2010, 2013, 2014, Sadhu et al. 2012, Wang et al. 2013), especially to the vegetation (Donggan et al. 2011) and to soil structure (Ghose 1996, 2004, Dutta and Agrawal 2002, Banerjee et al. 2004, Sadhu et al. 2012, Wang et al. 2013), mining waste disposal (Singh and Singh 2006, Bian et al. 2010, Bhuiyan et al. 2010, Wang et al. 2013), air pollution (Querol et al. 2008, Zhao et al. 2008, León-Mejia et al. 2011), and landscape changes (Bian et al. 2010).

The most important coal reservoirs in Brazil are in the states of Santa Catarina and Rio Grande do Sul, in the south sector of Paraná Basin (Kalkreuth et al. 2006). The Catarinense Coal Basin (CCB) covers a polygon of approximately $1,200 \mathrm{~km}^{2}$ in the southeastern part of Santa Catarina state, between $28^{\circ} 48$ and $28^{\circ} 23 \mathrm{~S}$ and between $49^{\circ} 33$ and $49^{\circ} 15 \mathrm{~W}$ (ABCM 2017). Coal exploitation began approximately in the 1890s (Belolli et al. 2002) and since then has caused notable physical, chemical, and biological changes in the local and regional ecosystems (Leffa et al. 2010, Zocche et al. 2014).

Strip mining and underground coal-mining involve first the removal of several layers located upon the coal bed, which often contain iron sulfide minerals and other chemical environmental contaminants despite the low concentration in coal $(<30 \%)$ (Bhuiyan et al. 2010). During the strip-mining and underground coal mining activities (Bhuiyan et al. 2010, Bian et al. 2010) and procedures of coal preparation (Bian et al.
2010), several toxic materials are directly exposed to atmospheric conditions thus being subjected to weathering (Sengupta 1993, Younger 2004, Zhao et al. 2007, Kuter 2013). Even though the environmental laws of several countries state that coal-mining waste should be adequately managed, most of such waste is still transported to dumps, used to fill gullies, or piled as a hill (Bhuiyan et al. 2010).

Catarinense coal is characterized by high sulfide content and by pyrite and marcasite (Pires and Querol 2004, Silva et al. 2011), and the residues contain several environmentally relevant metals and metalloids such as $\mathrm{As}, \mathrm{Pb}, \mathrm{Cd}, \mathrm{Ni}, \mathrm{Cr}, \mathrm{Mn}, \mathrm{Be}$, $\mathrm{V}, \mathrm{U}, \mathrm{Zn}, \mathrm{Li}, \mathrm{Cu}, \mathrm{Co}, \mathrm{Fe}, \mathrm{Hg}$ and $\mathrm{Ge}$ (Zocche et al. 2010, 2014, Silva et al. 2011). Currently, in the $\mathrm{CCB}$, the coal waste is discarded appropriately; however, in the past, until the 1980s, it had been carelessly disposed of anywhere (Zocche et al. 2010) and often deposited near mines as waste rocks or mining refuse, and for a long time, this waste had been used as embankment, road pavement, or a building construction material. The waste was also frequently used as embankment in wetlands, mainly in periurban areas, where later, low-income populations came to live and to cultivate vegetables in home gardens.

Food safety is one of the major public concerns worldwide (Radwan and Salama 2006, Arora et al. 2008). In the last decades, the number of studies dealing with the increased risks to human health as a result of a diet based on foods contaminated with pesticides, heavy metals, and/or toxins has increased (D'Mello 2003, Radwan and Salama 2006, Arora et al. 2008). Among the most severe food contaminants are trace elements (Zaidi et al. 2005). In general, heavy metals are not biodegradable, their biological half-life is very long, and they have a great potential for accumulation in various organs of the human body (Arora et al. 2008). In addition, Arora et al. (2008) pointed out that once inside a living organism, several heavy metals 
replace essential nutrients, thus causing metabolic biochemical disorders (Järup 2003, Sathawara et al. 2004) that affect human health and development (Wang et al. 2013) to some extent.

Keeping in mind the potential toxicity, persistent nature, and cumulative behavior of heavy metals as well as the consumption of vegetables grown on deposits of coal-mining waste that are rich in toxic elements in the $\mathrm{CCB}$, it is necessary to analyze concentrations of these contaminants. The aim of this study was to test (by means of an animal model) whether the vegetables cultivated in a vegetable garden built on deposits of coalmining waste accumulate chemical elements at a concentration that can represent a risk to human health.

\section{MATERIALS AND METHODS}

COLLECTION OF SOIL SAMPLES AND

VEGETABLES AND PREPARATORY PROCEDURES

Soil samples $(n=30)$ from the depth of 10 to 15 $\mathrm{cm}$ (Allen 1989) and samples $(\mathrm{n}=30$ each) of lettuce (Lactuca sativa L.), beet (Beta vulgaris L.), broccoli (Brassica oleracea L. var. italica), and kale (Brassica oleracea L. var. acephala) were randomly harvested once from the plots of a vegetable garden built over a deposit of tailings of mineral coal processing (coal-mining area), in the municipality of Forquilhinha, and from the plots of a certified organic farm (control area), located in the municipality of Criciúma, both of which are in the southern part of Santa Catarina state, Brazil. The coal tailing deposit was recovered in the last waste layer with $0.30 \mathrm{~m}$ of clay. On the clay layer, a top soil layer of $0.30 \mathrm{~m}$ was deposited, and on top of it, the vegetable garden plots were later constructed. The plots received a mixed layer of 0.30-0.40 m, composed of organic matter (litter chicken bedding), husk ash of rice, and topsoil. The vegetables produced in the coal-mining vegetable garden were used for feeding of the mine workers and distributed to their families.

The samples of each material (soil and each vegetable) from each site (coal-mining area and control area) were mixed to form a composite sample of soil per site and of each vegetable variety per site. Only the edible parts of vegetable samples were used for the analysis of elemental composition.

Soil samples were dried in an oven at $65-80{ }^{\circ} \mathrm{C}$ for $24 \mathrm{~h}$, ground to pass through a 200 -mesh $(0.075$ $\mathrm{mm}$ ) sieve, and homogenized for the analysis of elemental composition. The vegetables were washed first with tap water and then with deionized water to remove any possible foliar contaminants, such as dust or mud. The vegetables were then processed and separated in a centrifugal juicer, and one portion of the juice was stored in a refrigerator $\left(4{ }^{\circ} \mathrm{C}\right)$ until administration to the animals. The other part of the juice was oven-dried at $65-80{ }^{\circ} \mathrm{C}$ until all the water was removed. The dried material of each vegetable variety was then ground using a ceramic mortar and pestle to reduce the dried mass material to a suitable size for analysis of elemental composition. The soil and vegetable samples were stored in a moisture-free atmosphere and finally pressed into pellets $(n=3$ per sample) for the analysis of elemental composition.

\section{EXPERIMENTAL DESIGN, COLLECTION OF LIVERS, AND PREPARATION OF THE SAMPLES}

In this study, we used 72 healthy male Swiss albino mice (bodyweight: 33-40 g; age: 4 weeks). The experimental design was approved by the ethics committee for animal use of Universidade do Extremo Sul Catarinense (CEUA - UNESC; Register $\mathrm{N}^{\mathrm{o}}$ 110/2011). The animals were randomized by weight and housed in polycarbonate cages with steel wire tops (six animals by cage). The cages were exposed to the alternating lightdark cycle of $12 \mathrm{~h}$ and maintained at a standard room temperature $\left(22 \pm 2{ }^{\circ} \mathrm{C}\right)$ and humidity $(55 \%$ 
$\pm 10 \%$ ). The mice were subsequently randomly distributed into two groups: acute (one-time) treatment and chronic treatment.

In the acute treatment group, the animals were subdivided into eight subgroups with six animals per group: control lettuce, coal-mining lettuce, control beet, coal-mining beet, control broccoli, coal-mining broccoli, control kale, and coal-mining kale. The animals received a single dose of juice $(0.1 \mathrm{ml} / \mathrm{kg})$ by gavage for evaluation of elemental composition of the liver. Twenty-four hours after the administration, the animals were euthanized by decapitation, their livers were rapidly removed, and one fraction was collected to analyze the elemental composition.

In the chronic treatment, the animals were subdivided into four groups with six animals per group: control lettuce, coal-mining lettuce, control kale, and coal-mining kale. The animals received a single daily dose of juice $(0.1 \mathrm{ml} / \mathrm{kg})$ by gavage for 30 days for evaluation of elemental composition of the liver. Twenty-four hours after the last dose of juice, the animals were euthanized by decapitation, their livers were rapidly collected, and a portion was set aside for analysis of elemental composition.

The mouse liver samples were dried in an oven at $60{ }^{\circ} \mathrm{C}$ for $48 \mathrm{~h}$, mixed to form composite (pooled) samples per group, macerated using a mortar and pestle, stored in a moisture-free atmosphere, and finally pressed into pellets ( $\mathrm{n}=3$ per group) for analysis of elemental composition.

ANALYSIS OF ELEMENTAL COMPOSITION OF THE SOIL, VEGETABLES, AND MURINE LIVER

The samples of soil, vegetables, and murine livers (n $=3$ samples per site, species, and animal subgroup) were then analyzed for elemental composition by the particle-induced X-ray emission (PIXE) method, according to the articles by $\mathrm{He}$ et al. (1993) and Johansson et al. (1995). This method has been used for the detection of trace and major elements in plants and other life forms owing to its multielemental nature, high sensitivity, simplicity, and high sample throughput (Mireles et al. 2004). The results were expressed in parts per million $(\mu \mathrm{g}$ $\mathrm{g}^{-1}$ ) on a dry weight basis as mean $\pm \mathrm{SD}$.

\section{STATISTICAL ANALYSIS}

Data were presented as mean $\pm \mathrm{SD}$. We used the Kolmogorov-Smirnov test to evaluate the normality of variables. The differences in the elemental composition of the soils and vegetable species between the two sites (farming organic and coal-mining area) as well as in the livers of mice exposed to vegetable juice from the coal-mining area and organic farming area were evaluated by Student's $t$ test $(\mathrm{P} \leq 0.05)$ in the GraphPad Prism software package, version 5.00 for Windows (GraphPad Software, San Diego, CA, USA).

\section{RESULTS}

\section{ELEMENTAL COMPOSITION OF THE SOILS}

Table I lists the total soil concentrations of chemical elements detected on a dry-weight basis $\left(\mu \mathrm{g} \mathrm{g}^{-1}\right)$; these values varied within the two studied areas. The soils of the vegetable garden from the coalmining area contain high levels of potentially toxic trace elements. The total soil concentrations of $\mathrm{Si}$, $\mathrm{P}, \mathrm{Cu}$, and $\mathrm{Zn}$ at this location are higher than the background world-soil average in accordance to reference values presented by Allen (1989).

In the coal-mining area, the absolute concentrations of all the elements under study were higher than those in the control area although not all elements showed significantly higher values. The highest total concentrations $(\mathrm{P} \leq 0.05)$ were registered for magnesium, sulfur, and zinc and $(\mathrm{P} \leq 0.01)$ for phosphorus and calcium in the soil collected from the vegetable garden built in the coalmining area. The observed highest (significantly different) concentrations of chemical elements can be ranked as follows: $\mathrm{Ca}>\mathrm{Mg}>\mathrm{P}>\mathrm{S}>\mathrm{Zn}$. 
TABLE I

Elemental composition $\left(\mu \mathrm{g} \mathrm{g}^{-1} \mathrm{dw}\right)$ of soil from control and coal-mining areas determined by PIXE analysis.

\begin{tabular}{|c|c|c|c|}
\hline \multirow[b]{2}{*}{ Chemical Elements } & \multicolumn{2}{|c|}{ Soil Total Content $\left(\mu \mathrm{g} \mathrm{g}^{-1} \mathrm{dw}\right)$} & \multirow[b]{2}{*}{$\begin{array}{c}\text { Background world-soil } \\
\text { average }^{1} \\
\end{array}$} \\
\hline & Control Area & Coal-mining Area & \\
\hline $\mathrm{Mg}$ & $2,676 \pm 488.10$ & $4,590 \pm 1,029^{\mathrm{a}}$ & $2,000-30,000$ \\
\hline $\mathrm{Si}$ & $361,200 \pm 34,310$ & $437,100 \pm 202,000$ & $100,000-300,000$ \\
\hline $\mathrm{P}$ & $964.70 \pm 0.10$ & $4,553 \pm 1,222^{b}$ & $200-2,000$ \\
\hline $\mathrm{S}$ & $268.70 \pm 59.48$ & $996.20 \pm 368.00^{\mathrm{a}}$ & $400-2,000$ \\
\hline $\mathrm{K}$ & $3,151 \pm 601.60$ & $5,992 \pm 1,743$ & $1,000-20,000$ \\
\hline $\mathrm{Ca}$ & $3,848 \pm 2,021$ & $20,010 \pm 4,400^{\mathrm{b}}$ & $5,000-20,000$ \\
\hline $\mathrm{Fe}$ & $34,060 \pm 1,701$ & $51,630 \pm 9,183$ & $5,000-100,000$ \\
\hline $\mathrm{Cu}$ & $110.3 \pm 0.01$ & $213.10 \pm 74.62$ & $5.0-100$ \\
\hline $\mathrm{Zn}$ & $82.84 \pm 48.03$ & $384.30 \pm 109.80^{\mathrm{a}}$ & $20-300$ \\
\hline
\end{tabular}

${ }^{1}$ Source: Allen (1989); ${ }^{\mathrm{a}} \mathrm{p} \leq 0.05$ compared with reference area value (Student $\mathrm{t}$ test); ${ }^{\mathrm{b}} \mathrm{p} \leq 0.01$ compared with reference area value (Student $t$ test).

\section{ELEMENTAL COMPOSITION OF THE VEGETABLES}

Elemental composition of the juice from edible parts of the four analyzed vegetables is shown in Table II. We found that the total concentrations differed between the studied areas and among the vegetable varieties. Some of them are higher in the vegetable varieties from the control area than those from the coal-mining area and vice versa. The total concentrations of $\mathrm{Mg}, \mathrm{P}, \mathrm{S}$, and $\mathrm{K}$ in the juice of beets, broccoli, and kale from both areas were higher than the natural concentrations in plant material in accordance with the reference values published by Allen (1989). The same was true for $\mathrm{P}$ and $\mathrm{K}$ in the lettuce juice and for $\mathrm{Ca}$ in the juice of kale. Ca content of the broccoli juice from the control area, $\mathrm{Zn}$ content of broccoli juice and of kale juice from the coal-mining area, and $\mathrm{Fe}$ content of the juice of lettuce from the control area were also higher than the natural concentrations in plant material.

The concentrations of $\mathrm{P}$ were higher $(\mathrm{P} \leq$ 0.01 ) in the samples of the coal-mining area for all the vegetable varieties under study, whereas the concentrations of $\mathrm{Si}, \mathrm{K}$, and $\mathrm{Zn}$ were higher in the samples from the coal-mining area only for three of the four vegetable varieties. Si content was higher in beets $(\mathrm{P} \leq 0.001)$, broccoli $(\mathrm{P} \leq 0.01)$, and lettuce $(\mathrm{P} \leq 0.05) ; \mathrm{K}$ contents were higher in broccoli $(\mathrm{P} \leq$ $0.001)$, kale $(\mathrm{P} \leq 0.01)$, and beet $(\mathrm{P} \leq 0.05)$; and $\mathrm{Zn}$ contents were higher in broccoli, kale $(\mathrm{P} \leq 0.001)$ and in beets $(\mathrm{P} \leq 0.05)$. The concentrations of $\mathrm{Ca}$ and Fe were higher in the samples from the coal-mining area in two of the four vegetables. Ca contents were higher in beets $(\mathrm{P} \leq 0.001)$ and lettuce $(\mathrm{P} \leq 0.01)$, and $\mathrm{Fe}$ contents were higher in beets $(\mathrm{P} \leq 0.001)$ and broccoli $(\mathrm{P} \leq 0.01) . \mathrm{Mg}$ contents were higher $(\mathrm{P}$ $\leq 0.01)$ in samples of the coal-mining area in one of the four vegetables analyzed (in beets).

It was also found that the total concentrations of several elements were higher in vegetables from the control area than in the vegetables of the same variety from the coal-mining area (Table II). This was the case for $\mathrm{Mg}, \mathrm{S}, \mathrm{K}(\mathrm{P} \leq 0.001)$, and $\mathrm{Cu}(\mathrm{P} \leq$ $0.05)$ in lettuce; $\mathrm{S}(\mathrm{P} \leq 0.001)$ and $\mathrm{Cu}(\mathrm{P} \leq 0.05)$ in beets; for $\mathrm{Mg}, \mathrm{Ca}(\mathrm{P} \leq 0.001)$, and $\mathrm{S}(\mathrm{P} \leq 0.01)$ in broccoli; and for $\mathrm{Mg}(\mathrm{P} \leq 0.001)$ and $\mathrm{Ca}(\mathrm{P} \leq 0.01)$ in kale. 


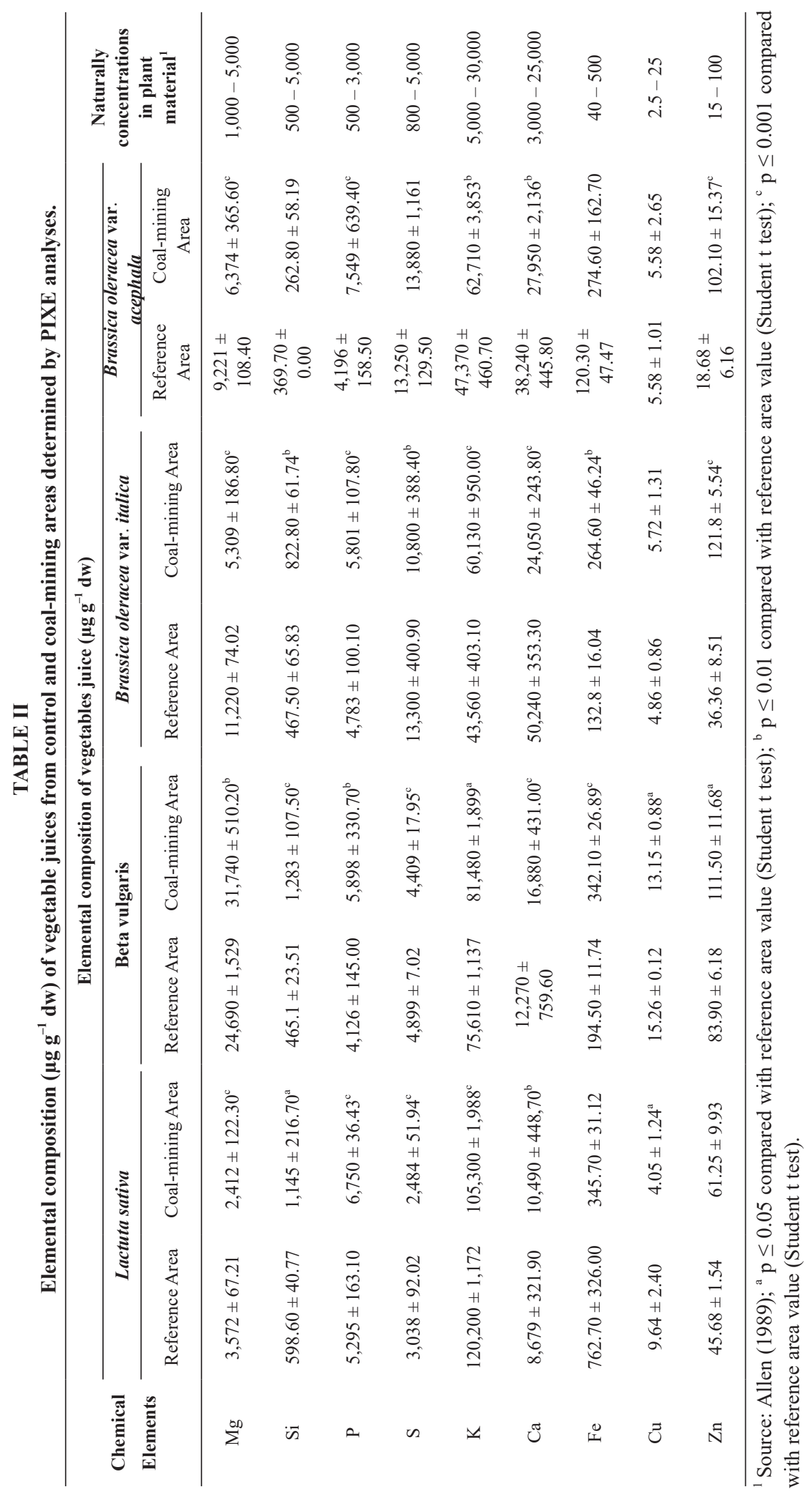


ELEMENTAL COMPOSITION OF THE LIVER IN MICE SUBJECTED TO ACUTE TREATMENT

Elemental composition of the liver in mice subjected to one-time consumption of juice of the vegetables is shown in Table III. In the case of broccoli, we found that the concentrations of $\mathrm{Mg}, \mathrm{S}(\mathrm{P} \leq 0.05)$, and $\mathrm{Ca}(\mathrm{P} \leq 0.01)$ were higher in the livers of the coal-mining area animal group in comparison with the control area group. As for kale, the concentrations of $\mathrm{Mg}, \mathrm{Si}, \mathrm{S}$, and $\mathrm{Ca}(\mathrm{P} \leq$ 0.05 ) in the coal-mining area group were higher than in the control area group. On the other hand, the animal groups that received the juice of beets and of lettuce from the coal-mining area showed no changes in the liver concentrations, for all the chemical elements studied, as compared with the control area group.

Only the total concentrations of S in the liver of mice subjected to one-time consumption of the juice of broccoli and of kale from the coal-mining area were higher than the natural concentrations in animal tissues published by Allen (1989).

\section{ELEMENTAL COMPOSITION OF THE LIVER IN MICE SUBJECTED TO CHRONIC TREATMENT}

The elemental composition of the liver in the mice subjected to chronic consumption of the juice of vegetables collected in the control area and in the coal-mining area is shown in Table IV. After comparing the coal-mining area group with the control area group that received the juices of vegetables, we found that in relation to lettuce, the concentrations of $\mathrm{P}, \mathrm{K}(\mathrm{P} \leq 0.001)$, and $\mathrm{Cu}(\mathrm{P} \leq$ $0.01)$ were higher in the livers of the animals that received the juice from the coal-mining area in comparison with the control area group of mice. The concentrations of $\mathrm{Fe}(\mathrm{P} \leq 0.01)$ were lower in the liver of the animals that consumed the juice from the coal-mining area in comparison with the control area group. With respect to kale, the concentrations of Si $(\mathrm{P} \leq 0.01), \mathrm{P}, \mathrm{K}, \mathrm{Fe}$, and $\mathrm{Zn}$
$(\mathrm{P} \leq 0.001)$ were higher in the liver of the mouse group that received the juice from the coal-mining area in comparison with the control area group.

Only the total concentrations of S in the liver of the mice subjected to chronic consumption of the juice of lettuce and of kale from both areas were higher than the natural concentrations in animal tissues reported by Allen (1989).

\section{DISCUSSION}

Coal-mining activities in the BCC generate a large amount of waste rocks and tailings that are deposited at the surface near the mines in lowland areas. The land surface is damaged, and the waste rocks and tailings that are environmentally unstable have become the sources of pollution. This scenario generally leads to changes in physicochemical characteristics of the soil and, consequently, the toxic elements are taken up by vegetable crops.

The total concentration of a chemical element in the soil is not a good measure of short-term bioavailability (because this concentration is not a very useful tool for analysis of the potential risk of toxicity in the case of plant and/or soil contamination). Nevertheless, total concentration of a chemical element can often indicate a potential availability, in addition to usefulness for reporting of the soil relations among elements and their quantity and distribution in a soil profile (Camargo et al. 2009, Kabata-Pendias 2010).

Our results show that all the analyzed elements are present at higher concentrations in the coalmining area than in the control area although not all elements showed significantly higher values. The highest total concentrations were registered for $\mathrm{Mg}\left(4,590 \pm 1,029 \mu \mathrm{g} \mathrm{g}^{-1}\right), \mathrm{P}(4,553 \pm 1,222$ $\left.\mu \mathrm{g} \mathrm{g}^{-1}\right), \mathrm{S}\left(996.20 \pm 368.00 \mu \mathrm{g} \mathrm{g}^{-1}\right), \mathrm{Ca}(20,010 \pm$ $\left.4,400 \mu \mathrm{g} \mathrm{g}^{-1}\right)$, and $\mathrm{Zn}\left(384.30 \pm 109.80 \mu \mathrm{g} \mathrm{g}^{-1}\right)$ in the vegetable garden soil of the coal-mining area. Bhuiyan et al. (2010), while studying heavy metal content of agricultural soils affected by coal-mining 


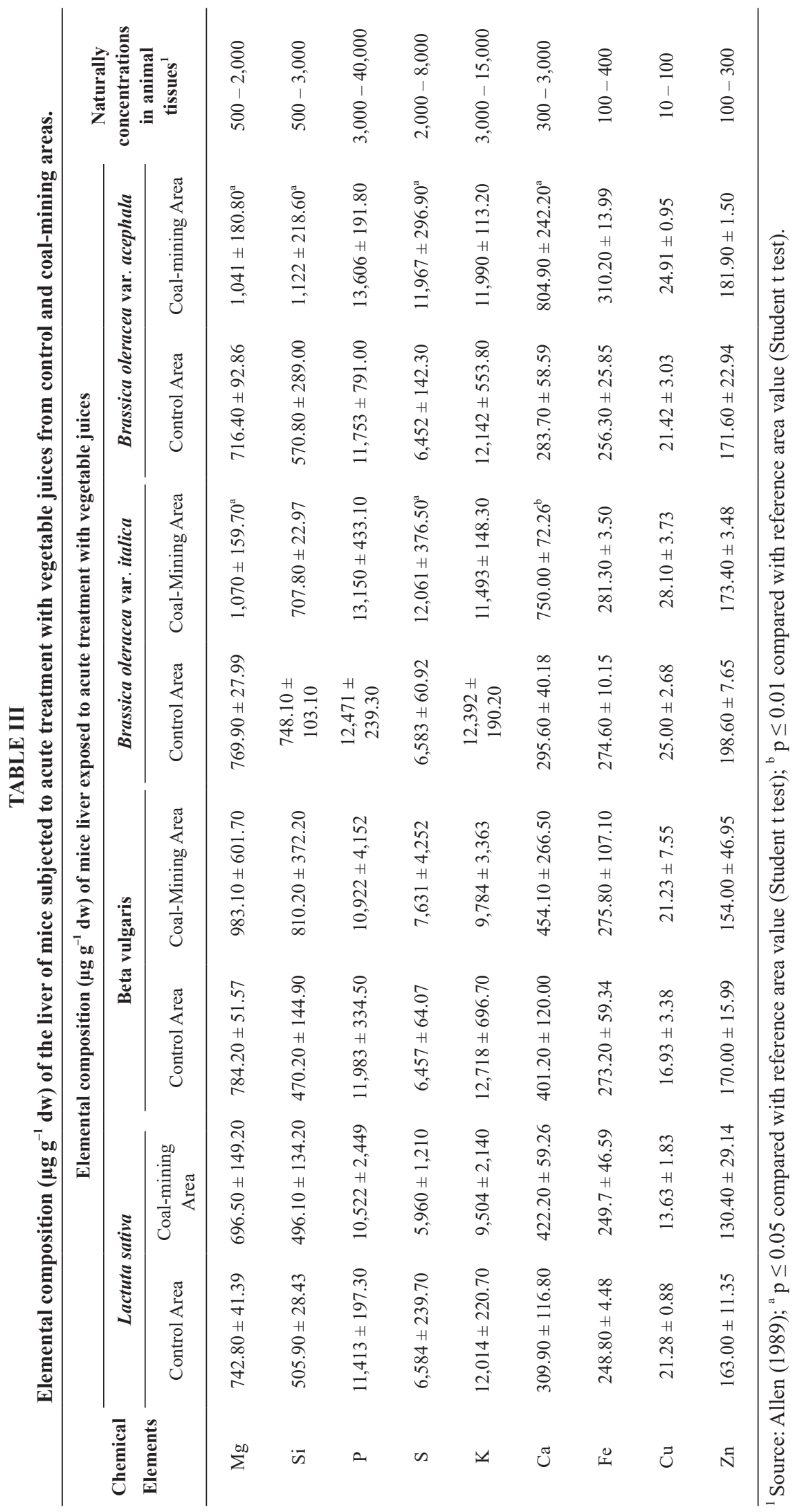




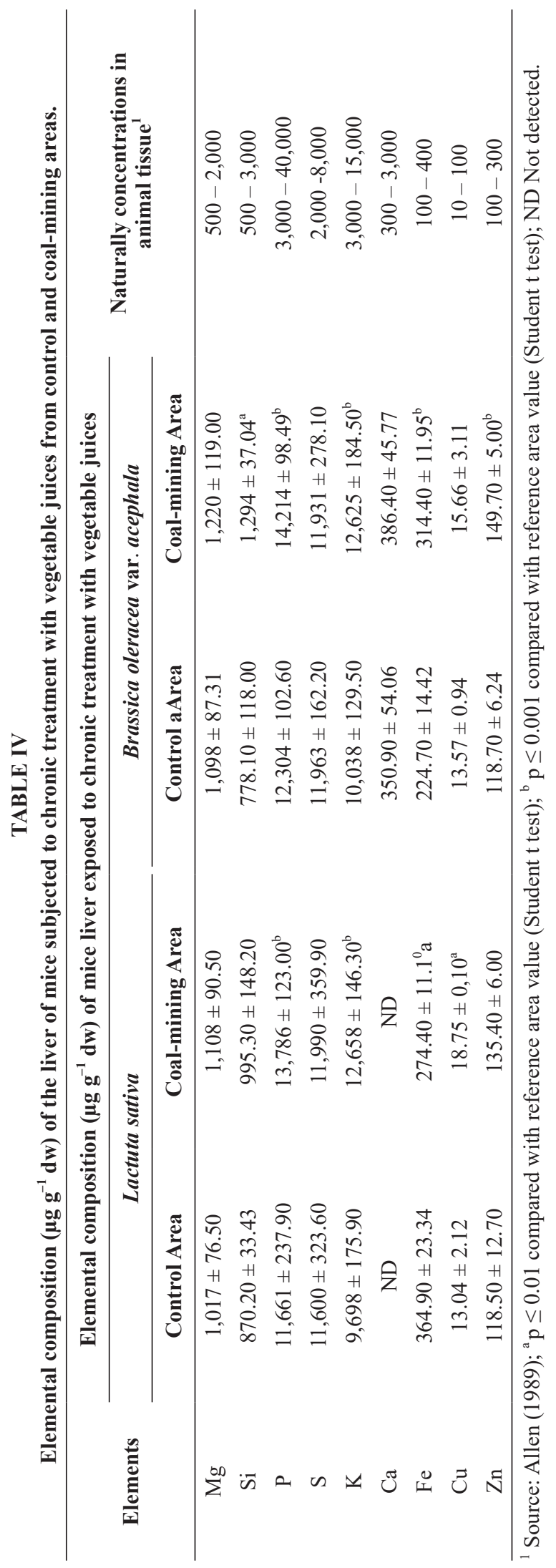

activities in northern Bangladesh, observed total concentrations of $\mathrm{K}, \mathrm{Ca}$, and $\mathrm{Zn}$ in the range of $10,400-24,400 \mathrm{mg} \mathrm{kg}^{-1}(17,360 \pm 4348), 12,600-$ $77,000 \mathrm{mg} \mathrm{kg}^{-1}(33,520 \pm 17,053)$, and $129-470$ $\mathrm{mg} \mathrm{kg}^{-1}(296 \pm 111)$, respectively.

Total concentrations of macronutrients $\mathrm{P}$ and $\mathrm{Ca}$ in the soil of the coal-mining vegetable garden were 4,553 \pm 1.22 and $20,010 \pm 4,400 \mu \mathrm{g} \mathrm{g}^{-1}$, respectively; whereas in native soils (control area), they were only $964.70 \pm 0.10$ and 3,848 $\pm 2,021 \mu \mathrm{g}$ $\mathrm{g}^{-1}$, respectively. P plays several roles in cellular process of plants, e.g., participation in the synthesis of compounds, gas exchange, energy storage and transfer, and cell division and enlargement (Sadhu et al. 2012), whereas $\mathrm{Ca}$ is a relatively common constituent of several soil minerals (Kabata-Pendias 2010) and is responsible for tolerance of plants to toxic effects of heavy metals ( $\mathrm{Al}, \mathrm{Cu}$, and $\mathrm{Mn})$, in addition to performing some functions in the formation and integrity of cellular wall membranes (Malavolta 1976).

Regarding the other elements (e.g., heavy metals), Sadhu et al. (2012), while analyzing mine spoil soils of Raniganj Coal Field West Bengal, India, recorded extractable maximum concentrations of $\mathrm{Fe}$ as being the highest at 35.76 $\mathrm{g} \mathrm{kg}^{-1}, \mathrm{Cu}$ at $17.25 \mathrm{~g} \mathrm{~kg}^{-1}$, and $\mathrm{Zn}$ at $47.47 \mathrm{~g} \mathrm{~kg}^{-1}$ although the differences in trace metal contents between the mine spoil and native soil were not significant. Bhuiyan et al. (2010) in turn pointed out in their study that the agricultural soils that were irrigated by mine drainage water contain high levels of potentially toxic trace elements although the total concentrations varied considerably depending on the location of the samples. The range of concentrations of $\mathrm{Fe}$ observed by then were as high as $36,300-78,000 \mathrm{mg} \mathrm{kg}^{-1}$ (mean $\pm \mathrm{SD}$ : $59,853 \pm 13,318 \mathrm{mg} \mathrm{kg}^{-1}$ ); $\mathrm{Zn}$ concentration was as high as $129-470 \mathrm{mg} \mathrm{kg}^{-1}\left(296 \pm 70 \mathrm{mg} \mathrm{kg}^{-1}\right)$. These values are very similar to our results on Fe contents $\left(51,630 \pm 9,183 \mu \mathrm{g} \mathrm{g}^{-1}\right)$ and $\mathrm{Zn}(384.30 \pm 109.80$ $\left.\mu \mathrm{g} \mathrm{g}^{-1}\right)$ in the vegetable garden on coal-mining 
soil. Bhuiyan et al. (2010) concluded that the $\mathrm{Zn}$ concentrations recorded in their study are likely to pose a risk to human health and to the environment, suggesting that our $\mathrm{Zn}$ values have the same status. Türkdoğan et al. (2002), while investigating the levels of seven heavy metals $(\mathrm{Co}, \mathrm{Cd}, \mathrm{Pb}, \mathrm{Zn}, \mathrm{Mn}$, $\mathrm{Ni}$, and $\mathrm{Cu}$ ) in soil, fruit, and vegetable samples of the Van region in Eastern Turkey (where upper gastrointestinal cancers are endemic), recorded soil concentrations of $\mathrm{Cu}$ as high as 9-31 $\mu \mathrm{g} \mathrm{g}^{-1}(20 \pm$ 6) and of $\mathrm{Zn}$ as high as 6-28.5 $\mu \mathrm{g} \mathrm{g}^{-1}(12.1 \pm 6.1)$. Again, these values are very similar to our results on $\mathrm{Cu}$ content $\left(213.10 \pm 74.62 \mu \mathrm{g} \mathrm{g}^{-1}\right)$ and much lower than $\mathrm{Zn}$ content of the coal-mining vegetable garden soil. This finding once more suggests that our results are likely to be of concern in terms of human health and environmental protection.

Our data show that concentrations of some chemical elements such as $\mathrm{P}, \mathrm{Si}, \mathrm{K}, \mathrm{Zn}, \mathrm{Ca}, \mathrm{Mg}$, and $\mathrm{Fe}$ were higher in some vegetables from the coal-mining area, whereas concentrations of other elements such as $\mathrm{Mg}, \mathrm{S}, \mathrm{K}, \mathrm{Cu}$, and $\mathrm{Ca}$ were higher in some vegetables from the control area. These results corroborate the general tendency of genotypic variations in relation to accumulation of chemical elements by vegetables: reported by Alexander et al. (2006) as low in legumes, moderate in root vegetables, and high in leafy vegetables. Our results also corroborate the findings of KabataPendias (2010), who stated that although biological selection of chemical elements allows plants to control their chemical composition to a certain extent; these control mechanisms are somewhat limited with respect to trace elements. Therefore, concentrations of trace elements in plants often positively correlate with the abundance of these elements in soils and even in underlying rocks.

In the vegetable juice from the coal-mining area, we recorded concentrations of $\mathrm{Mg}$ ranging from $2,412 \pm 122$ to $31,740 \pm 510 \mu \mathrm{g} \mathrm{g}^{-1}$, Si values from $262.80 \pm 58.19$ to $1,283 \pm 107.50 \mu \mathrm{g} \mathrm{g}^{-1}$, $\mathrm{P}$ concentrations from $5,801 \pm 107.80$ to 7,549 $\pm 639.40 \mu \mathrm{g} \mathrm{g}^{-1}, \mathrm{~S}$ values from $2,484 \pm 51.84$ to $13,880 \pm 1,161 \mu \mathrm{g} \mathrm{g}^{-1}, \mathrm{~K}$ values from $60,130 \pm 950$ to $105,300 \pm 1,988 \mu \mathrm{g} \mathrm{g}^{-1}$, Ca values from 10,490 \pm 448.70 to $27,950 \pm 2,136 \mu \mathrm{g} \mathrm{g}^{-1}, \mathrm{Fe}$ values from $264.60 \pm 46.24$ to $345.70 \pm 31,12 \mu \mathrm{g} \mathrm{g}^{-1}, \mathrm{Cu}$ values from $4.05 \pm 1.24$ to $13.15 \pm 0.88 \mu \mathrm{g} \mathrm{g}^{-1}$, and $\mathrm{Zn}$ from $61.25 \pm 9.93$ to $121.8 \pm 5.54 \mu \mathrm{g} \mathrm{g}^{-1}$. Dogheim et al. (2004) recorded $\mathrm{Cu}$ values of $0.92 \mathrm{mg} \mathrm{kg}^{-1}$ in Egyptian lettuces; Bahemuka and Mubofu (1999) recorded $\mathrm{Cu}$ values ranging from 0.25 to $0.58 \mathrm{mg} \mathrm{kg}^{-1}$ and $\mathrm{Zn}$ values ranging from 1.48 to $1.59 \mathrm{mg} \mathrm{kg}^{-1}$ in lettuce from Tanzania; Onianwa et al. (2001), in turn, reported $\mathrm{Cu}$ and $\mathrm{Zn}$ values of 0.72 and $2.30 \mathrm{mg} \mathrm{kg}^{-1}$, respectively, in lettuce from Nigeria. In fruits and vegetables, Türkdoğan et al. (2002) recorded $\mathrm{Cu}$ values ranging from 54 to $105 \mu \mathrm{g} \mathrm{g}^{-1}(70 \pm 16)$ and $\mathrm{Zn}$ concentrations as high as $19-89 \mu \mathrm{g} \mathrm{g}^{-1}(44 \pm 22)$. Radwan and Salama (2006), while studying the heavy-metal contents of Egyptian vegetable and fruit components of the market basket, recorded values of $\mathrm{Cu}$ in lettuce ranging from 1.82 to $2.22 \mathrm{mg} \mathrm{kg}^{-1}(1.97 \pm 0.07)$ and $\mathrm{Zn}$ as high as 7.8 to $12 \mathrm{mg} \mathrm{kg}^{-1}(9.76 \pm 0.07)$.

The values of $\mathrm{Cu}$ and $\mathrm{Zn}$ detected in the vegetable juice from the coal-mining area, in this study in general, without considering the vegetables in particular, are much higher than those shown in leafy vegetables by the authors cited above. Our concentrations of $\mathrm{Cu}$ and $\mathrm{Zn}$ in the lettuce juice from the coal-mining area are higher than those reported by Dogheim et al. (2004), Bahemuka and Mubofu (1999), and Onianwa et al. (2001) [and higher than only $\mathrm{Zn}$ values reported by Türkdoğan et al. (2002)]. The authors cited earlier concluded that environmental toxins, heavy metals, and poor nutrition seem to play important etiological roles in carcinogenesis.

Our analysis of elemental composition of juice from the edible parts of vegetables from the coalmining area shows that concentrations of elements in the juice in general, without considering the vegetable varieties, were in the order $\mathrm{K}>\mathrm{Mg}>$ 
$\mathrm{Ca}>\mathrm{S}>\mathrm{P}>\mathrm{Si}>\mathrm{Fe}>\mathrm{Zn}>\mathrm{Cu}$. If we analyzed each species only for heavy metal contents, we found that the order is $\mathrm{Fe}>\mathrm{Zn}>\mathrm{Cu}$ for all the vegetables analyzed. These results corroborate the data of Arora et al. (2008), who assessed the heavymetal content of edible parts of vegetables irrigated with water from different sources (fresh water, wastewater, and unknown source of irrigation) in India.

Differences in metal contents of the vegetable juice between the coal-mining area and the control area depend on the physical and chemical nature of the soil and the absorption capacity of the plant varieties for each metal. These characteristics are affected by various factors such as environmental and human interference, and the species of the plant (Brooks 1983, Zurera-Cosano et al. 1989). All our vegetables have lower levels of $\mathrm{Cu}$ and higher levels of $\mathrm{Zn}$ than the maximum permissible values in food $\left(40 \mathrm{mg} \mathrm{kg}^{-1}\right.$ for $\mathrm{Cu}$ and $60 \mathrm{mg}$ $\mathrm{kg}^{-1}$ for $\mathrm{Zn}$ ) proposed by Food and Agriculture/ World Health Organization (FAO/WHO) (Codex Alimentarius Commission 1984). The same tendency was observed, except for lettuce, in the natural concentrations in plant material presented by Allen (1989).

To assess the health risk of a pollutant, it is necessary to estimate the exposure level by detecting the routes of exposure for the target life forms. There are many possible pathways of exposure for humans but among them, the food chain is the most important one. Accordingly, we used mice subjected to one-time or chronic consumption of vegetable juice and analyzed the hepatic elemental composition since the liver is the first organ to be affected by chemical elements in the metabolism. In the mouse group subjected to acute treatment, the highest intakes of $\mathrm{Mg}, \mathrm{S}$, and $\mathrm{Ca}$ came from the consumption of broccoli juice and kale juice, both of which were from the coal-mining area. The kale juice also provided the highest intake of Si. In contrast, in the mouse group subjected to chronic treatment, the highest intakes of $\mathrm{P}, \mathrm{K}$, and $\mathrm{Cu}$ came from the consumption of lettuce juice and kale juice, both of which were from the coal-mining area, whereas the highest intakes of $\mathrm{Si}, \mathrm{P}, \mathrm{K}, \mathrm{Fe}$, and $\mathrm{Zn}$ came from kale juice.

The plant productivity on agricultural soils affected by heavy-metal pollution is an environmental concern because the presence of heavy metals in the soils can affect not only the plant productivity but also food quality as well as human health through the food chain (Alloway 1990, McGrath et al. 2002, Kabata-Pendias 2010). For example, $\mathrm{Cu}, \mathrm{Mn}$, and $\mathrm{Zn}$ are essential plant nutrients (Marschner and Marschner 2012), but they can be toxic at elevated concentrations (KabataPendias 2010). When any or several of these elements are present in soil above their respective background concentrations, remedial actions may be necessary (Zheljazkov et al. 2008). Considering the solubility in water, most of heavy metals are extremely toxic. Several animal species, including humans, have no good mechanism for elimination of heavy metals; this situation makes most of heavy metals highly toxic even at low concentrations in the body (Arora et al. 2008).

Plants absorb trace elements via roots from soils or other growth media and via above-ground parts from aerial deposition (Bahemuka and Mubofu 1999, Kabata-Pendias 2010) and accumulate them in their edible (Bahemuka and Mubofu 1999) and inedible parts (Alam et al. 2003) in quantities that can cause health problems in animals (including humans) consuming these metal-rich plants (Alam et al. 2003). Vegetables concentrate heavy metals in different quantities in grains, leaves, fruits, and roots (Kabata-Pendias 2010). Mapanda et al. (2005) pointed out that heavy metals accumulate at higher concentrations in parts of leafy vegetables than in grains and fruits.

A number of serious human health problems can develop as a result of excessive dietary intake of heavy metals (Arora et al. 2008). The presence 
of some heavy metals at high concentrations in food is closely related to the prevalence of a number of diseases, especially cardiovascular, kidney, nervous-system, and bone diseases (WHO 1992, 1995, Steenland and Boffetta 2000, Järup 2003). In addition, heavy metals are implicated in carcinogenesis, mutagenesis, and teratogenesis (IARC 1993, Pitot and Dragan 1996). Nevertheless, some heavy metals such as $\mathrm{Cu}$ and $\mathrm{Zn}$ perform important roles in the biochemical and physiological functions that are essential to maintenance of life. Apart from its function as a biocatalyst, $\mathrm{Cu}$ is necessary for body pigmentation (as is $\mathrm{Fe}$ ), for the maintenance of a healthy central nervous system, and for prevention of anemia, and it is interrelated with the functions of $\mathrm{Zn}$ and $\mathrm{Fe}$ in the human body (Akinyele and Osibanjo 1982). Zn deficiency results in a variety of immunological problems, whereas $\mathrm{Cu}$ deficiency is characterized by anemia, neutropenia, and skeletal aberrations (Prentice 1993, ATSDR 1994, Linder and HazeghAzam 1996).

Several heavy metals can stimulate production of reactive oxygen species (ROS), thereby causing lipid peroxidation, DNA damage, and oxidative damage (Stohs and Bagchi 1995, Henkler et al. 2010, Leffa et al. 2010, Zocche et al. 2013, 2014) and alterations in $\mathrm{Ca}$ homeostasis (Stohs and Bagchi 1995). Heavy metals initiate and enhance the neoplastic process by liberation of ROS and by causing DNA mutations (Peeters 1987, Feig et al. 1994). A large body of research has revealed the carcinogenic effects of several heavy metals (Feig et al. 1994, Trichopoulos 1997) and other chemical elements. $\mathrm{Cu}$, for example, increases the risk of hepatocellular and renal carcinoma according to animal studies (Eagon et al. 1999, Giri et al. 1999); several chromosomal anomalies were reported in $\mathrm{Zn}$ and $\mathrm{Pb}$ miners (Jackson 1988, Bilban 1998); and hepatocellular and esophageal cancers are the most frequent malignant tumors $(45.4 \%$ and $19.8 \%$ prevalence, respectively) reported in gold miners in
South Africa (Bradshaw et al. 1982). The incidence of gastric cancer is also higher in coal miners (Türkdoğan et al. 2002). After studying coalmining areas, León-Mejía et al. (2011) concluded that the exposure to coal-mining residues may result in increased genotoxic exposure among coalmining workers.

Coal-mining waste contains substantial amounts of toxic heavy metals, thus creating problems (Singh et al. 2004, Chen et al. 2005). Excessive accumulation of heavy metals in coalmining waste or in soils constructed over coalmining waste deposits may not only result in soil contamination or a decrease in the crop production but also can compromise the food quality and safety (Muchuweti et al. 2006, Arora et al. 2008, Zocche et al. 2010, 2013, 2014).

We must take into account that the vegetable garden in the coal-mining area studied here was constructed carefully to prevent absorption of toxic elements of coal waste by the greenery. The construction had the objective to provide food for meals at work and for distribution to the workers' families. Although the coal-mining area vegetable garden was constructed carefully, we found that $\mathrm{P}, \mathrm{Si}, \mathrm{K}, \mathrm{Ca}, \mathrm{Mg}, \mathrm{Zn}$, and Fe concentrations were higher in the samples from the coal-mining area in at least one of the vegetables under study. Thus, what are we supposed to think about the vegetable gardens that are built on a land that is grounded in coal waste and has received no treatment to prevent the absorption of toxic elements by plants?

We know that when several chemical elements are present in the soil, plants, or in food above their respective background concentrations, they can cause human health problems through their toxic and genotoxic effects. In Brazil, only limited data are available on heavy metals in cereals, fruits, medicinal plants, meat, and leafy vegetables; therefore, this study shows the first data on the concentrations of chemical elements in vegetables from coal-mining areas. Our results also alerted 
us to the dangers for people who eat food made of plants grown on soils affected by coal-mining activities.

As pointed out by Khairiah et al. (2004), Chojnacka et al. (2005), and Kabata-Pendias (2010), plants exposed to a contaminated soil take up and accumulate heavy metals in roots, leaves, seeds, and fruits. As people are encouraged to consume more fruits and vegetables - which are a good source of vitamins, minerals, and fiber and are generally beneficial to health - a regular public policy of surveys and programs must be implemented for monitoring of elemental composition of foods produced in areas affected by coal-mining. This is because these plants contain both essential and toxic metals in a wide range of concentrations, which can do more harm than good.

\section{CONCLUSIONS}

Elemental composition (elements under study) differs between the studied areas and among vegetable varieties. Total concentrations of five chemical elements (Mg, P, S, Ca, and Zn) are higher in the soil of the coal-mining vegetable garden in comparison with the control area. Concentrations of four elements ( $\mathrm{Si}, \mathrm{P}, \mathrm{Cu}$, and $\mathrm{Zn}$ ) out of the nine studied are higher in the soil of the coal-mining vegetable garden than the background concentration (the world-soil average). The concentrations of all the analyzed chemical elements in the vegetable juice from the coal-mining area, except for Si and $\mathrm{Cu}$, are, in accordance with the literature data, higher than the natural concentrations defined for vegetables, in at least one of the four vegetable varieties under study. Although only the total concentrations of $\mathrm{S}$ in the liver of mice exposed to acute or chronic treatment are higher than the natural concentrations in animal tissues, we found that the concentrations of $\mathrm{Mg}, \mathrm{S}$, and $\mathrm{Ca}$ in the liver of the mice that consumed the juice of broccoli and the concentrations of $\mathrm{Mg}, \mathrm{Si}, \mathrm{S}$, and $\mathrm{Ca}$ in the liver of the animals that consumed the juice of kale from the coal-mining area are higher relative to the control area groups.

Thus, we recommend that people be careful in relation to consumption of vegetables that grow directly on mineral coal waste, on thin soils constructed over coal waste, cultivated in a vegetable garden built over coal waste deposits, or irrigated with mine acid drainage. In the long run, dietary intake of vegetables from these sites can result in high accumulation of trace elements in the body. The detrimental effects will become apparent only after several years of exposure.

It is necessary to regularly monitor the concentrations of toxic chemical elements in constructed soils in coal-mining areas, in effluents, in mine acid drainage, and in plants and other kinds of food produced in coal-mining areas, to prevent the biomagnification phenomenon of heavy metals through the wild or human food chain as well as to prevent damage to human health. Further research is needed to determine definitively whether the elements studied here indeed have harmful effects on human health.

\section{ACKNOWLEDGMENTS}

This study was funded by the Programa de Iniciação Científica da Universidade do Extremo Sul Catarinense (PIBIC/UNESC), Conselho Nacional de Desenvolvimento Científico e Tecnológico (CNPq), Secretaria da Educação do Estado de Santa Catarina (SED - SC), and Coordenação de Aperfeiçoamento de Pessoal de Nível Superior (CAPES).

\section{REFERENCES}

ABCM. 2017. http://www.carvaomineral.com.br. AKINYELE IO AND OSIBANJO O. 1982. Levels of some trace elements in hospital diets. Food Chem 8: 247-251.

ALAM MGM, SNOW ET AND TANAKA A. 2003. Arsenic and heavy metal contamination of vegetables grown in Samta village, Bangladesh. Sci Total Environ 308: 83-96. 
ALEXANDER PD, ALLOWAY BJ AND DOURADO AM. 2006. Genotypic variations in the accumulation of $\mathrm{Cd}, \mathrm{Cu}$, $\mathrm{Pb}$ and $\mathrm{Zn}$ exhibited by six commonly grown vegetables. Environ Pollut 144: 736-745.

ALLEN SE. 1989. Chemical analysis of ecological materials, $2^{\text {nd }}$ ed., London: Blackwell Scientific Publications, 380 p.

ALLOWAY BJ. 1990. Soil processes and the behavior of metals. In: Alloway BJ (Ed), Heavy metals in soils, New York: Blackie and Son Inc., p. 7-28.

ARORA M, KIRAN B, RANI S, RANI R, KAUR K AND MITTAL N. 2008. Heavy metal accumulation in vegetables irrigated with water from different sources. Food Chem 111: 811-815.

ATSDR. 1994. Toxicological profile for zinc. US Department of Health and Human Services, Public Health Services, Agency for Toxic Substance and Disease Registry, Atlanta, Georgia.

BAHEMUKA TE AND MUBOFU EB. 1999. Heavy metals in edible green vegetables grown along the sites of the Sinza and Msimbazi rivers in Dar es Salaam, Tanzania. Food Chem 66: 63-66.

BANERJEE S, MISHRA TK, SINGH AK AND JAIN A. 2004. Impact of plantation on ecosystem development in disturbed coal mine overburden spoils. J Trop For Sci 16: 294-307.

BELOLLI M, QUADROS J AND GUIDI A. 2002. A história do carvão de Santa Catarina, Criciúma: Imprensa Oficial do Estado de Santa Catarina, 300 p.

BHUIYAN MA, PARVEZ L, ISLAM MA, DAMPARE SB AND SUZUKIA S. 2010. Heavy metal pollution of coal mine-affected agricultural soils in the northern part of Bangladesh. J Hazard Mater 173: 384-392.

BIAN Z, INYANG H, DANIELS J, OTTO F AND STRUTHERS S. 2010. Environmental issues from coal mining and their solutions. Mining Science and Technology (China) 20: 215-223.

BILBAN M. 1998. Influence of the work environment in a Pb$\mathrm{Zn}$ mine on the incidence of cytogenetic damage in miners. Am J Ind Med 34: 455-463.

BRADSHAW E, MCGLASHAN ND, FITZGERALD D AND HARINGTON JS. 1982. Analyses of cancer incidence in black gold miners from Southern Africa (1964-79). Brit J Cancer 46: 737-748.

BROOKS RR. 1983. Biological methods of prospecting for minerals, $2^{\text {nd }}$ ed., California: Willey, $322 \mathrm{p}$.

CAMARGO O, DE MONIZ AC, JORGE, JA AND VALADARES JMAS. 2009. Métodos de análise química, mineralógica e física de solos do Instituto Agronômico de Campinas. Campinas: Instituto Agronômico, Boletim Técnico 106, $77 \mathrm{p}$.

CHEN Y, WANG C AND WANG Z. 2005. Residues and source identification of persistent organic pollutants in farmland soils irrigated by effluents from biological treatment plants. Environ Int 31: 778-783.

CHOJNACKA K, CHOJNACKI A, GORECKA H AND GORECKI H. 2005. Bioavailability of heavy metals from polluted soils to plants. Sci Total Environ 337: 175-182.

CODEX ALIMENTARIUS COMMISSION 1984. FAO/WHO Food Standards Program. Contaminants, $17^{\text {th }}$ Session of the Codex Committee on Food Additives. The Hague: FAO/WHO, $131 \mathrm{p}$.

COUNCIL WER. 2013. World energy resources, London: World Energy Council, 468 p.

D'MELLO JPF. 2003. Food safety: contaminants and toxins. Trowbridge: Cromwell Press, 469 p.

DOGHEIM S, EL-ASHRAF MM, GAD ALLA SA, KHORSHID MAAND FAHMY SM. 2004. Pesticides and heavy metals levels in Egyptian leafy vegetables and some aromatic medicinal plants. Food Addit Contam 21: 323330 .

DONGGAN G, ZHONGKE B, TIELIANG S, HONGBO S AND WEN Q. 2011. Impacts of coal mining on the aboveground vegetation and soil quality: a case study of Qinxin Coal Mine in Shanxi Province, China. Clean-Soil Air Water 39: 219-225.

DUTTA RK AND AGRAWAL M. 2002. Effect of tree plantations on the soil characteristics and microbial activity of coal mine spoil land. Trop Ecol 43: 315-324.

EAGON PK, TEEPE AG, ELM MS AND TADIC SD. 1999. Hepatic hyperplasia and cancer in rats: alterations in copper metabolism. Carcinogenesis 20: 1091-1096.

FEIG DI, REID TM AND LOEB LA. 1994. Reactive oxygen species in tumorigenesis. Cancer Res 54: 1890-1894.

GHOSE MK. 1996. Damage of land due to coal mining and conservation of top soil for land reclamation. Environ Ecol 14: 466-468.

GHOSE MK. 2004. Effect of opencast mining on soil fertility. J Sci Ind Res India 63: 1006-1009.

GIRI U, IQBAL M AND ATHAR M. 1999. Coppernitrilotriacetate $(\mathrm{Cu}-\mathrm{NTA})$ is a potent inducer of proliferative response both in liver and kidney but is a complete renal carcinogen. Int J Oncol 14: 799-806.

HE F, BUOSO MC, BURATTINI E, FAZINIC S, GALASSINI S, HAQUE AMI, JAKSIC M AND MOSCHINI G. 1993. Target preparation for trace element determination of biological materials using nuclear techniques. Nucl Instrum Meth A 334: 238-245.

HENKLER F, BRINKMANN J AND LUCH A. 2010. The role of oxidative stress in carcinogenesis induced by metals and xenobiotics. Cancers 2: 376-396.

IARC. 1993. Cadmiun and cadmiun compounds. In: Beryllium, cadmium, mercury, and exposures in the glass manufacturing industry. Iarc Monog Eval Carc 58: 119237. 
JACKSON M. 1988. Selenium: geochemical distribution and associations with human heart and cancer death rates and longevity in China and the United States. Biol Trace Elem Res 15: 13-21.

JÄRUP L. 2003. Hazards of heavy metal contamination. Brit Med Bull 68: 167-182.

JOHANSSON SAE, CAMPBELL JL AND MALMQVIST KG. 1995. Particle-induced X-ray emission spectrometry (PIXE), New York: Wiley-Interscience, $451 \mathrm{p}$.

KABATA-PENDIAS A. 2010. Trace elements in soils and plants, $4^{\text {th }}$ ed., Boca Raton: CRC Press, $520 \mathrm{p}$.

KALKREUTH W, HOLZ M, KERN M, MACHADO G, MEXIAS A, SILVA MB, WILLETT J, FINKELMAN R AND BURGER H. 2006. Petrology and chemistry of Permian coals from the Paraná Basin: 1. Santa Terezinha, Leão-Butiá and Candiota coalfields, Rio Grande do Sul, Brazil. Int J Coal Geol 68: 79-116.

KHAIRIAH J, ZALIFAH MK, YIN YH AND AMINAH A. 2004. The uptake of heavy metals by fruit type vegetables grown in selected agricultural areas. Pakistan Journal of Biological Sciences 7: 1438-1442.

KUTER N. 2013. Reclamation of degraded landscapes due to opencast mining. In: Özyavuz M (Ed), Advances in landscape architecture, Croatia: InTech, p. 823-858.

LEFFA DD, DAMIANI AP, SILVA J, ZOCCHE JJ, SANTOS CEI, BOUFLEUR LA, DIAS JF AND ANDRADE VM. 2010. Evaluation of the genotoxic potential of the mineral coal tailings through the Helix aspersa (Mülller, 1774). Arch Environ Contam Toxicol 59: 614-621.

LEÓN-MEJIA G, ESPITIA-PÉREZ L, HOYOS-GIRALDO LS, Da SILVA J, HARTMANN A, HENRIQUES JA AND QUINTANA M. 2011. Assessment of DNA damage in coal open-cast mining workers using the cytokinesis-blocked micronucleus test and the comet assay. Sci Total Environ 409: 686-691.

LINDER MC AND HAZEGH-AZAM M. 1996. Copper biochemistry and molecular biology. Am J Clin Nutr 63: 797-811.

MALAVOLTA E. 1976. Manual de química agrícola: nutrição de plantas e fertilidade do solo, São Paulo: Agronômica Ceres, $528 \mathrm{p}$.

MAPANDA F, MANGWAYANA EN, NYAMANGARA J AND GILLER KE. 2005. The effect of long-term irrigation using wastewater on heavy metal contents of soils under vegetables in Harare, Zimbabwe. Agr Ecosyst Environ 107: 151-165.

MARSCHNER H AND MARSCHNER P. 2012. Marschner's mineral nutrition of higher plants, $3^{\text {rd }}$ ed., San Diego: Academic press, $672 \mathrm{p}$.

MCGRATH S, ZHAO FJ AND LOMBI E. 2002. Phytoremediation of metals, metalloids, and radionuclides. Adv Agron 75: 1-56.
MIRELES A, SOLÍS C, ANDRADE E, LAGUNAS-SOLAR M, PINA C AND FLOCCHINI RG. 2004. Heavy metal accumulation in plants and soil irrigated with wastewater from Mexico City. Nucl Instrum Meth B 220: 187-190.

MUCHUWETI M, BIRKETT JW, CHINYANGA E, ZVAUYA R, SCRIMSHAW MD AND LESTER JN. 2006. Heavy metal content of vegetables irrigated with mixtures of wastewater and sewage sludge in Zimbabwe: implications for human health. Agr Ecosyst Environ 112: 41-48.

ONIANWA P, ADEYEMO AO, IDOWU OE AND OGABIELA EE. 2001. Copper and zinc contents of Nigerian foods and estimates of the adult dietary intakes. Food Chem 72: 89-95.

PEETERS EG. 1987. The possible influence of the components of the soil and the lithosphere on the development and growth of neoplasms. Experientia 43: 74-81.

PIRES M AND QUEROL X. 2004. Characterization of Candiota (South Brazil) coal and combustion by-product. Int J Coal Geol 60: 57-72.

PITOT HAND DRAGAN YP. 1996. Chemical carcinogenesis. In: Klaassen CD (Ed), Toxicology, $5^{\text {th }}$ ed., New York: McGraw Hill, p. 241-319.

PRENTICE A. 1993. Does mild zinc deficiency contribute to poor growth performance? Nutr Rev 5: 268-270.

QUEROL X, IZQUIERDO M, MONFORT E, ALVAREZ E, FONT O, MORENO T, ALASTUEY A, ZHUANG X, LU W AND WANG Y. 2008. Environmental characterization of burnt coal gangue banks at Yangquan, Shanxi Province, China. Int J Coal Geol 75: 93-104.

RADWAN MA AND SALAMA AK. 2006. Market basket survey for some heavy metals in Egyptian fruits and vegetables. Food Chem Toxicol 44: 1273-1278.

SADHU K, ADHIKARI K AND GANGOPADHYAY A. 2012. Effect of mine spoil on native soil of Lower Gondwana coal fields: Raniganj coal mines areas, India. Int J Environ Sci 2: 1675-1687.

SATHAWARA N, PARIKH DJ AND AGARWAL YK. 2004. Essential heavy metals in environmental samples from western India. B Environ Contam Tox 73: 756-761.

SENGUPTA M. 1993. Environmental impacts of mining monitoring, restoration, and control, Boca Raton: CRC Press LLC, $512 \mathrm{p}$.

SILVA LFO, WOLLENSCHLAGER M AND OLIVEIRA MLS. 2011. A preliminary study of coal mining drainage and environmental health in the Santa Catarina region, Brazil. Environ Geochem Hlth 33: 55-65.

SINGH A AND SINGH J. 2006. Experiments on ecological restoration of coal mine spoil using native trees in a dry tropical environment, India: a synthesis. New Forest 31: 25-39.

SINGH KP, MOHAN D, SINHA S AND DALWANI R. 2004. Impact assessment of treated/untreated wastewater toxicants discharged by sewage treatment plants on health, 
agricultural, and environmental quality in the wastewater disposal area. Chemosphere 55: 227-255.

STEENLAND K AND BOFFETTA P. 2000. Lead and cancer in humans: where are we now? Am J Ind Med 38: 295-299.

STOHS S AND BAGCHI D. 1995. Oxidative mechanisms in the toxicity of metal ions. Free Radical Bio Med 18: 321-336.

TRICHOPOULOS D. 1997. Epidemiology of cancer. In: Devita VT (Ed), Cancer, principles and practice of oncology, Philadelphia: Lippincott Company, p. 231-258.

TÜRKDOĞAN MK, KILICEL F, KARA K, TUNCER I AND UYGA I. 2002. Heavy metals in soil, vegetables and fruits in the endemic upper gastrointestinal cancer region of Turkey. Environ Toxicol Phar 13: 175-179.

WANG J, LIU W, YANG R, ZHANG L AND MA J. 2013. Assessment of the potential ecological risk of heavy metals in reclaimed soils at an opencast coal mine. Disaster Adv 6: 366-377.

WHO. 1992. Cadmium. Environ Health Crit 134.

WHO. 1995. Inorganic lead. Environ Health Crit 165.

YOUNGER PL. 2004. Environmental impacts of coal mining and associated wastes: a geochemical perspective. Geol Soc 236: 169-209.

ZAIDI MI, ASRAR A, MANSOOR A AND FAROOQUI MA. 2005. The heavy metal concentration along roadside trees of Quetta and its effects on public health. J Appl Sci 5: 708-711.

ZAKRZEWSKI SF.1991. Principles of environmental toxicology, $1^{\text {st }}$ ed., Washington: American Chemical Society, $270 \mathrm{p}$.

ZHAO F, CONG Z, SUN H AND REN D. 2007. The geochemistry of rare earth elements (REE) in acid mine drainage from the Sitai coal mine, Shanxi Province, North China. Int J Coal Geol 70: 184-192.

ZHAO Y, XU X, SUN W, HUANG B, DARILEK JL AND SHI X. 2008. Uncertainty assessment of mapping mercury contaminated soils of a rapidly industrializing city in the Yangtze River Delta of China using sequential indicator co-simulation. Environ Monit Assess 138: 343-355.

ZHELJAZKOV VD, JELIAZKOVA EA, KOVACHEVA N AND DZHURMANSKI A. 2008. Metal uptake by medicinal plant species grown in soils contaminated by a smelter. Environ Exp Bot 64: 207-216.

ZOCCHE JJ, DAMIANI AP, HAINZENREDER G, MENDONÇA RA, PERES PB, DOS SANTOS CE, DEBASTIANI R, DIAS JF AND ANDRADE VM. 2013. Assessment of heavy metal content and DNA damage in Hypsiboas faber (anuran amphibian) in coal open-casting mine. Environ Toxicol Pharmacol 36: 194-201.

ZOCCHE JJ, DA SILVA LA, DAMIANI AP, MENDONÇA RA, PERES PB, DOS SANTOS CE, DEBASTIANI R, DIAS JF, ANDRADE VM AND PINHO RA. 2014 Heavy-metal content and oxidative damage in Hypsiboas faber: the impact of coal-mining pollutants on amphibians. Arch Environ Contam Toxicol 66: 69-77.

ZOCCHE JJ, LEFFA DD, PAGANINI AD, CARVALHO F, MENDONÇA RA, SANTOS CEL, BOUFLEUR LA, DIAS JF AND ANDRADE VM. 2010. Heavy metals and DNA damage in blood cells of insectivore bats in coal mining areas of Catarinense coal basin, Brazil. Environ Res 110: 684-691.

ZURERA-COSANO G, MORENO R, SALMERON J and POZO R. 1989. Heavy metal uptake from greenhouse border soils for edible vegetables. J Sci Food Agr 49: $307-$ 314. 